\title{
Gut microbiota, cognitive frailty and dementia in older individuals: a systematic review
}

This article was published in the following Dove Press journal:

Clinical Interventions in Aging

\section{Andrea Ticinesi ${ }^{1-3}$ \\ Claudio Tana ${ }^{2}$ \\ Antonio Nouvenne ${ }^{2,3}$ \\ Beatrice Prati ${ }^{2}$ \\ Fulvio Lauretani ${ }^{2}$ \\ Tiziana Meschi ${ }^{1-3}$}

'Department of Medicine and Surgery, University of Parma, Parma, Italy; ${ }^{2}$ Geriatric-Rehabilitation Department, Parma University Hospital, Parma, Italy; ${ }^{3}$ Microbiome Research Hub, University of Parma, Parma, Italy
Correspondence: Andrea Ticinesi Geriatric-Rehabilitation Department, Parma University Hospital, Parma, Italy; Via Antonio Gramsci 14, Parma 43I26, Italy

Tel +39347 I84 519|

Email andrea.ticinesi@unipr.it
Abstract: Cognitive frailty, defined as the coexistence of mild cognitive impairment symptoms and physical frailty phenotype in older persons, is increasingly considered the main geriatric condition predisposing to dementia. Recent studies have demonstrated that gut microbiota may be involved in frailty physiopathology by promoting chronic inflammation and anabolic resistance. The contribution of gut microbiota to the development of cognitive impairment and dementia is less defined, even though the concept of "gut-brain axis" has been well demonstrated for other neuropsychiatric disorders. The aim of this systematic review was to summarize the current state-of-the-art literature on the gut microbiota alterations associated with cognitive frailty, mild cognitive impairment and dementia and elucidate the effects of pre- or probiotic administration on cognitive symptom modulation in animal models of aging and human beings. We identified 47 papers with original data (31 from animal studies and 16 from human studies) suitable for inclusion according to our aims. We concluded that several observational and intervention studies performed in animal models of dementia (mainly Alzheimer's disease) support the concept of a gut-brain regulation of cognitive symptoms. Modulation of vagal activity and bacterial synthesis of substances active on host neural metabolism, inflammation and amyloid deposition are the main mechanisms involved in this physiopathologic link. Conversely, there is a substantial lack of human data, both from observational and intervention studies, preventing to formulate any clinical recommendation on this topic. Gut microbiota modulation of cognitive function represents, however, a promising area of research for identifying novel preventive and treatment strategies against dementia.

Keywords: microbiome, Alzheimer's disease, vascular dementia, mild cognitive impairment, dysbiosis

\section{Introduction}

\section{Cognitive frailty and dementia in the clinical setting}

Cognitive frailty is a geriatric condition defined as the coexistence of the physical frailty syndrome and cognitive impairment, in the absence of a clinical diagnosis of Alzheimer's disease (AD) or other types of dementia. ${ }^{1}$ This condition has gained great attention from the scientific community in the last decade, and is being studied more for its physiopathologic, epidemiologic and clinical aspects. ${ }^{2-4}$

Several studies, which have been comprehensively reviewed by Panza et al, support the concept that cognitive frailty is a clinical entity distinct from the classical construct of the "frailty syndrome", in spite of a significant overlap between the two conditions. ${ }^{3}$ The frailty concept, operationalized according to either the Fried phenotype model or the Rockwood deficit accumulation model, is, in fact, mainly centered on measures of physical performance and presence of functional deficits. ${ }^{5}$ However, population-based studies have shown that, among community-dwelling older individuals diagnosed with 
frailty, those carrying signs of mild cognitive impairment (MCI) have poorer outcomes, supporting cognitive frailty as a distinct physiopathologic and clinical syndrome., ${ }^{6,7}$

As such, clinical tools for frailty risk assessment are increasingly incorporating cognition and measures of cognitive function, ${ }^{8}$ supporting the need for a combined assessment of motoric and cognitive function for frailty identification in real-world clinical settings. ${ }^{9}$ Disentangling physical and cognitive frailty phenotypes may be particularly challenging in clinical practice, since motoric and cognitive symptoms may coexist. Older community dwellers with cognitive impairment often have low gait speed, which represents one of the frailty phenotype criteria. ${ }^{10}$ Low gait speed is, in fact, the main motoric manifestation of cognitive frailty. ${ }^{11}$

Even if there is an international consensus on cognitive frailty definition, ${ }^{1}$ the operative diagnostic criteria are not completely standardized across clinical and epidemiologic studies. The critical issues concern both the evaluation of cognitive symptoms (diagnosis of MCI or clinical dementia rating scale score of 0.5 ) and of frailty (Fried criteria or a modified version of Cardiovascular Health Study criteria). The criteria used in the Italian Longitudinal Study on Aging ${ }^{7}$ are reported in Table 1. In this study, MCI was diagnosed using a battery of neuropsychological tests and not the clinical dementia rating scale, ${ }^{7}$ in line with the most recent consensus recommendations. ${ }^{12}$ However, in other studies,

Table I Summary of the clinical criteria for cognitive frailty assessment

Presence of mild cognitive impairment (all the following criteria must be fulfilled)

- Cognitive concern with a change in cognition reported by the patient or caregivers

- Objective evidence of impairment in one or more cognitive domains, including memory, at neuropsychological tests

- Preservation of independence in functional abilities

- No evidence of dementia

Absence of an identifiable cause of cognitive impairment in personal history

Presence of frailty phenotype according to the Fried criteria modified by the Cardiovascular Health Study criteria

(At least three out of five criteria must be fulfilled)

- Unintentional weight loss $>5 \mathrm{~kg}$ in the last year, with affirmative response to the question, "Do you think that your clothes are wide?"

- Exhaustion, defined as Geriatric Depression Scale-30 score $\geq 10$ and negative answer to the question, "Do you feel full of energy?"

- Weakness with inability to stand from a chair unaided and without using the arms

- Slowness (time $\geq 7$ seconds to walk $5 \mathrm{~m}$ )

- Low physical activity (patient reporting being inactive or performing only light physical activity) a Mini-Mental State Examination test score $\leq 25$ was used as a simplified method for assessing cognitive symptoms. ${ }^{13}$

In cross-sectional studies, cognitive frailty was associated with higher prevalence of obesity, low functional performance and disability than physical frailty. ${ }^{13-15}$ In longitudinal studies, it also predicted several patient-centered outcomes, including disability, malnutrition, diagnosis of dementia, hospital admission and length of stay, nursing home admission and mortality. ${ }^{11,16-21}$

Cognitive frailty may be reversible, particularly in those patients where cognitive frailty is diagnosed based only on subjective cognitive decline (clinical dementia rating scale score 0.5 ) in the absence of a certified MCI. ${ }^{7}$ Early identification of this condition, through measurement of reliable biomarkers, is thus pivotal for secondary prevention of dementia. ${ }^{22,23}$ Understanding the pathophysiology of cognitive frailty represents a priority of geriatric research and could help elucidate some important mechanisms of dementia development.

\section{Frailty and microbiota}

The main factors possibly involved in the onset of cognitive frailty are specific personality traits, depression, cardiac dysfunction, cardiovascular diseases, sarcopenia, dyslipidemia, insulin resistance, malnutrition and its precursor anorexia of aging, chronic inflammation and hormonal dysregulation including hypogonadism and hypovitaminosis D (Figure 1). ${ }^{3}$ Interestingly, most of these factors have been associated with alterations in the composition of the gut microbiota, that is, the ensemble of bacteria, fungi, viruses, protozoa and archaea symbiotically living in the distal human gastrointestinal tract. ${ }^{24}$

Changes in the gut microbiota composition have been recently associated with several human diseases and conditions, involving not only the gastroenteric system but also other distant organs. ${ }^{25}$ During aging, gut microbiota composition physiologically faces reduced species richness and increased interindividual variability. ${ }^{26}$ In 2012, Claesson et al demonstrated that these alterations are particularly observed in older subjects with physical frailty and living in nursing home, partly because of reduced mobility and variety in dietary habits. ${ }^{27}$

Since then, other studies have confirmed that the fecal microbiota of older individuals with physical frailty, mobility limitations and multimorbidity experience lower biodiversity and reduced representation of taxa with purported beneficial activity for the host physiology. ${ }^{28-32}$ In fact, many microbial taxa, underrepresented in frail older persons, may produce 


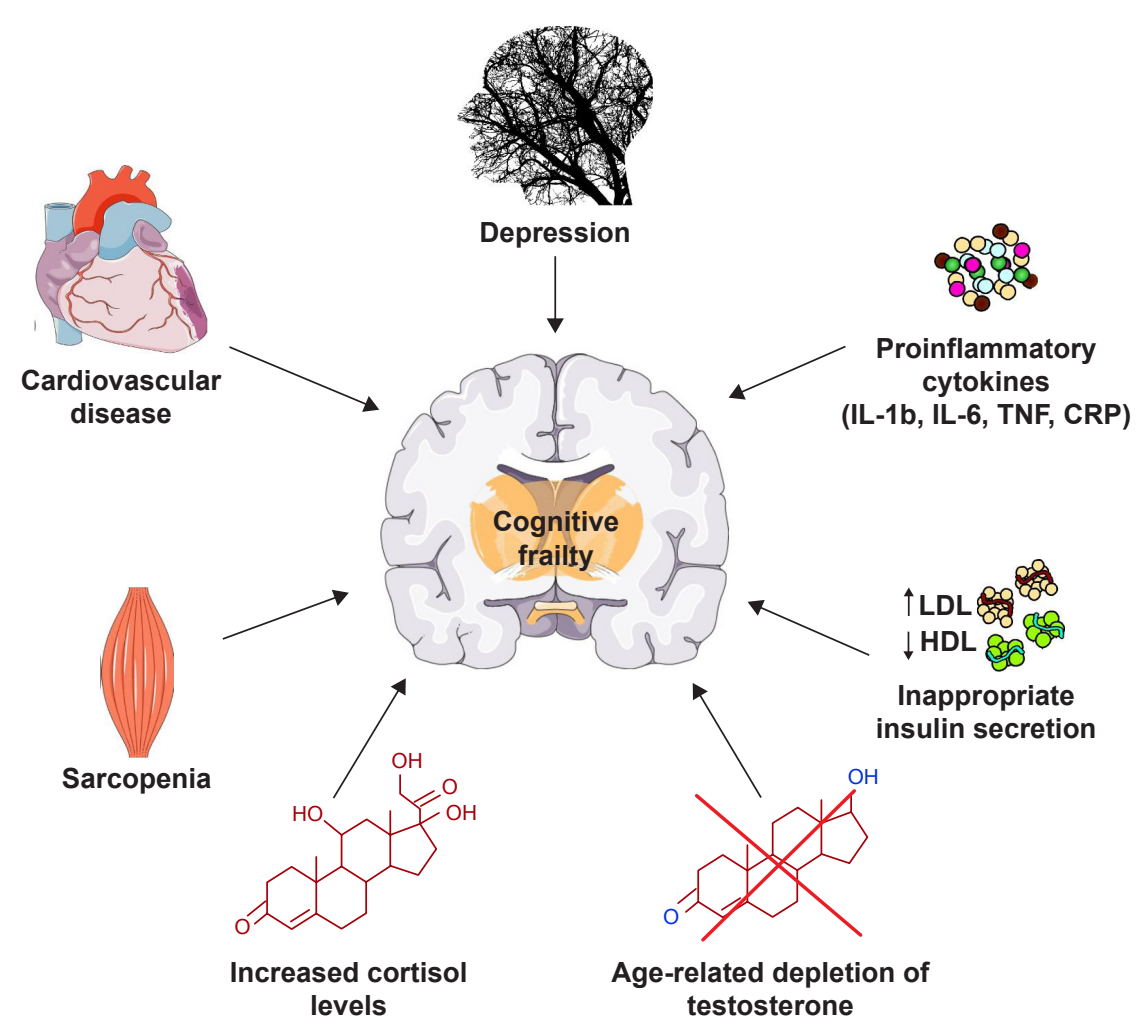

Figure I Schematic overview of the possible conditions and physiopathologic alterations associated with the onset and progression of cognitive frailty. Abbreviations: CRP, C-reactive protein; HDL, high-density lipoprotein; IL, interleukin; LDL, low-density lipoprotein; TNF, tumor necrosis factor.

metabolic mediators, such as short-chain fatty acids (SCFAs), modulating inflammation and improving insulin sensitivity and anabolic responses in the host physiology. ${ }^{33}$

On these grounds, some research groups have recently hypothesized an involvement of the gut microbiota in the physiopathology of physical frailty and age-related sarcopenia. ${ }^{34-36}$ A "gut-muscle axis" may, in fact, exist, with microbial mediators influencing skeletal muscle anabolism and, in turn, physical exercise favoring gut microbiota biodiversity. ${ }^{34-36}$

On the other side, the characteristics of gut microbiota in patients with cognitive frailty and their possible involvement in dementia are someway less defined. The presence of a gut-brain crosstalk has been, however, demonstrated in intestinal diseases,${ }^{37}$ cirrhosis ${ }^{38}$ and psychiatric disorders. ${ }^{39}$ Thus, an influence of gut microbiota in the physiopathology of cognitive frailty, MCI and dementia can be hypothesized. ${ }^{40}$

\section{Aims}

The aim of the present review is to summarize the current state-of-the-art literature on the gut microbiota alterations associated with cognitive frailty, MCI and dementia in animal models of aging and older people. It also aims to clarify the role of microbiota modifications, through administration of pre- or probiotics, in modulating the course of cognitive symptoms in both settings.

\section{Materials and methods}

A systematic literature search was performed on public databases (PubMed, Scopus). All articles published from January 1, 2004, to April 30, 2018, were considered for inclusion. The literature published before this interval was not considered since it was the period before next-generation sequencing techniques boosted the research on gut microbiota. Search queries were the following: "cognitive frailty" AND microbiota OR microbiome; "mild cognitive impairment" AND microbiota OR microbiome; "cognitive impairment" AND microbiota OR microbiome; dementia AND microbiota OR microbiome; Alzheimer AND microbiota OR microbiome; Alzheimer's AND microbiota OR microbiome; "gut-brain axis" AND aging; frailty AND microbiota OR microbiome; "cognitive impairment" AND probiotics; dementia AND probiotics; Alzheimer AND probiotics; Alzheimer's AND probiotics; frailty AND probiotics.

The results for each query were individually checked for relevance within the scopes of the present review by reading titles and abstracts. Duplicate papers, that is, papers retrieved with different queries, were considered only once. 
Papers were excluded if the topic was not adherent to the theme of gut microbiota composition in patients or animal models with cognitive frailty, MCI or dementia. Papers with main text not in English language were excluded as well. Reviews were not included in the systematic literature analysis. However, they are considered and cited in the "Discussion" section if they provided original contributions in terms of hypotheses on the possible role of gut microbiota in modulating cognitive function and dementia physiopathology and the underlying mechanisms. Thus, only papers with original data on animal models or human patients were included in the results, and the full text was analyzed to retrieve the relevant information.

\section{Results}

\section{Literature search}

A total of 312 papers fulfilled the search queries and were thus considered for inclusion in this review. However, 206 of them were excluded since the topic did not fall within the scope of the present review, or because the main text was not in English language. Another 59 papers were review articles and were considered only for literature discussion. Thus, 47 original papers (16 with data from human subjects and 31 with data from animal models) were included in the present analysis. Studies on animal models and human beings were considered separately. Moreover, a distinction between observational/descriptive studies, not implying the administration of pre- or probiotics and exploring only the physiopathologic aspects of gut-brain axis, and intervention studies, with administration of pre- or probiotics, was also made.

\section{Observational/descriptive studies on animal models}

In aging mice, deficits in spatial memory and increases in anxious behavior may arise, indicating progression toward a neurodegenerative disorder similar to human dementia. In a observational study considering mice of different ages, these symptoms were correlated with increased gut permeability, increased systemic inflammation and overrepresentation of several bacterial taxa in the cecal microbiota, including Porphyromonadaceae, Odoribacter, Butyricimonas, Clostridium and Oxalobacter, a microbiome profile resembling to that of murine inflammatory bowel disease. ${ }^{41}$ The presence of gut microbiota dysbiosis also negatively influenced the immunological response and clinical outcomes of experimental mouse models of stroke, resulting in worse motoric and cognitive symptoms than those of mice with a healthy microbiota profile. ${ }^{42}$
Experimental models of mice genetically prone to AD, such as the transgenic APP/PS1 breed, generally have a normal gut microbiota profile in the young age, but a shift toward lower microbiota biodiversity and overrepresentation of taxa with proinflammatory activity, such as Odoribacter, Helicobacter and Sutterella, occurs with aging, according to two different studies. ${ }^{43,44}$ These mice also show dramatically increased gut mucosa permeability, with several bacteria-derived membrane vesicles that can be found in the blood and could influence amyloid plaque deposition in the brain. ${ }^{45}$ Interestingly, amyloid deposition was also observed in the gut tissue of murine AD models and it correlated with dysbiosis. ${ }^{46}$ In a recent observational study, mice genetically prone to $\mathrm{AD}$ exhibited a distinct fecal microbiota composition than healthy controls, with reduced biodiversity and altered functionality. ${ }^{47}$ Especially, the production of SCFAs by the gut microbiota was reduced, with possible negative effects on amyloid deposition in both the brain and the gut. ${ }^{47}$

Absence of the physiological bacterial diversity between cecum and colon, overrepresentation of Firmicutes and decreased microbial metabolism of unsaturated fatty acids and choline, worsened by high-fat diets, were also demonstrated in 3xtg mice, another transgenic model of dementia. ${ }^{48}$ Even in Drosophila models of dementia, the presence of intestinal dysbiosis was associated with worsened inflammation and activation of brain neurodegeneration pathways mediated by TNF-JNK. ${ }^{49}$

Other studies investigated the effects of induced gut microbiota dysbiosis on cognitive function and gut-brain signaling of mouse models of dementia. ${ }^{50-54}$ The results, summarized in Table 2, highlight the role of gut microbiota in regulating neuroinflammation, cerebral amyloid deposition and clearance, hippocampal synthesis of mediators or receptors involved in neurotransmission. ${ }^{50-54}$ Bacterial metabolites and circulating miRNAs have been hypothesized as playing a pivotal role in this gut-brain crosstalk..$^{52,53}$ Interestingly, antibiotic-induced dysbiosis may not necessarily imply unfavorable consequences on brain pathology. In fact, Minter et al showed that antibiotic administration to mice genetically prone to $\mathrm{AD}$ during their postnatal development resulted in reduced deposition of $\mathrm{A} \beta$ amyloid in the brain. ${ }^{54}$

\section{Observational studies on humans}

The role of gut microbiota alterations in driving cognitive symptoms of human subjects was first studied in the context of advanced cirrhosis. In the fecal microbiota of a small group of patients with hepatic encephalopathy, Bajaj et al found overrepresentation of Enterobacteriaceae and Fusobacteriaceae, and identified some taxa, namely Alcaligenaceae 
Table 2 Summary of animal studies investigating the effects of induced gut microbiota dysbiosis on the host physiology and cognitive function

\begin{tabular}{|c|c|c|c|c|c|}
\hline $\begin{array}{l}\text { First author, } \\
\text { journal, } \\
\text { year (ref) }\end{array}$ & $\begin{array}{l}\text { Animal } \\
\text { model }\end{array}$ & Exposure & $\begin{array}{l}\text { Outcomes } \\
\text { measured }\end{array}$ & Main results & $\begin{array}{l}\text { Proposed mechanisms } \\
\text { of intestinal microbiota } \\
\text { involvement in dementia } \\
\text { physiopathology }\end{array}$ \\
\hline $\begin{array}{l}\text { Harach, Sci } \\
\text { Rep, } 2017^{50}\end{array}$ & $\begin{array}{l}\text { APPPSI } \\
\text { transgenic } \\
\text { mice }\end{array}$ & $\begin{array}{l}\text { Germ-free } \\
\text { mice obtained } \\
\text { by IVF and } \\
\text { bred in aseptic } \\
\text { environment }\end{array}$ & $\begin{array}{l}\text { Cerebral amyloid } \\
\text { deposition }\end{array}$ & $\begin{array}{l}\text { Lower cerebral amyloid deposition } \\
\text { in germ-free mice than controls; } \\
\text { increased amyloid deposition in germ- } \\
\text { free mice receiving fecal microbiota } \\
\text { transplantation from controls }\end{array}$ & $\begin{array}{l}\text { Gastrointestinal bacteria may } \\
\text { promote subclinical neural } \\
\text { inflammation facilitating } \\
\text { amyloid deposition }\end{array}$ \\
\hline $\begin{array}{l}\text { Minter, Sci } \\
\text { Rep, } 2016^{51}\end{array}$ & $\begin{array}{l}\mathrm{APP}_{S W E} / P S I_{\triangle E 9} \\
\text { transgenic } \\
\text { mice }\end{array}$ & $\begin{array}{l}\text { Long-term } \\
\text { broad- } \\
\text { spectrum } \\
\text { combinatorial } \\
\text { antibiotic } \\
\text { therapy }\end{array}$ & $\begin{array}{l}\text { A } \beta \text { amyloid deposition } \\
\text { Soluble } A \beta \text { levels } \\
\text { Cerebral glial } \\
\text { reactivity } \\
\text { Circulating cytokine } \\
\text { and chemokine levels }\end{array}$ & $\begin{array}{l}\text { Antibiotic-treated mice showed higher } \\
\text { circulating cytokine and chemokine, } \\
\text { reduced cerebral } A \beta \text { plaque deposition, } \\
\text { increased glial activity and } A \beta \text { circulating } \\
\text { levels }\end{array}$ & $\begin{array}{l}\text { Gut dysbiosis may facilitate } \\
\text { neuroinflammation with } \\
\text { positive consequences in } \\
\text { the acute phase (reduced } \\
\text { A } \beta \text { plaque deposition) and } \\
\text { detrimental consequences in } \\
\text { the long term }\end{array}$ \\
\hline $\begin{array}{l}\text { Fröhlich, Brain } \\
\text { Behav Immun, } \\
2016^{52}\end{array}$ & Adult mice & $\begin{array}{l}\text { Intragastric } \\
\text { treatment } \\
\text { with multiple } \\
\text { antibiotics }\end{array}$ & $\begin{array}{l}\text { Metabolic profile of } \\
\text { the colon } \\
\text { Microbial circulating } \\
\text { metabolites } \\
\text { Expression of } \\
\text { neuronal signaling } \\
\text { molecules } \\
\text { Cognitive behavior }\end{array}$ & $\begin{array}{l}\text { Gut microbiota dysbiosis associated } \\
\text { with decreased colonic and circulating } \\
\text { microbial metabolites, reduced neural } \\
\text { signaling-related molecules in the brain, } \\
\text { increased cytokine representation in the } \\
\text { amygdala and hippocampus and impaired } \\
\text { novel object recognition memory }\end{array}$ & $\begin{array}{l}\text { Microbial metabolite } \\
\text { depletion in the gut may act } \\
\text { as endocrine messengers, } \\
\text { altering neural signaling } \\
\text { molecule (BDNF, NMDA } \\
\text { receptor, serotonin } \\
\text { transporter, NPY) synthesis } \\
\text { particularly in the amygdala } \\
\text { and hippocampus }\end{array}$ \\
\hline $\begin{array}{l}\text { Cui, BBA Mol } \\
\text { Basis Dis, } \\
2017^{53}\end{array}$ & $\begin{array}{l}\text { C57BL/6J } \\
\text { mice }\end{array}$ & $\begin{array}{l}\text { Total } \\
\text { abdominal } \\
\text { irradiation }\end{array}$ & $\begin{array}{l}\text { Intestinal and } \\
\text { circulating miRNAs } \\
\text { Brain BDNF } \\
\text { expression } \\
\text { Gut microbiota } \\
\text { composition }\end{array}$ & $\begin{array}{l}\text { Irradiation-induced cognitive deficits, gut } \\
\text { microbiota dysbiosis, overexpression } \\
\text { of circulating miR-34a-5p and reduced } \\
\text { expression of hippocampal BDNF } \\
\text { Injection of miR-34a-5p antagonists } \\
\text { restored BDNF production and gut } \\
\text { microbiota eubiosis }\end{array}$ & $\begin{array}{l}\text { Gut microbiota may } \\
\text { mediate cognitive } \\
\text { function through miRNA } \\
\text { expression (particularly } \\
\text { miR-34a-5p) - a bidirectional } \\
\text { gut-brain crosstalk mediated } \\
\text { by miRNAs may exist }\end{array}$ \\
\hline $\begin{array}{l}\text { Minter, Sci } \\
\text { Rep, } 2017^{54}\end{array}$ & $\begin{array}{l}\mathrm{APP}_{S W E} / P S I_{\triangle E 9} \\
\text { transgenic } \\
\text { mice }\end{array}$ & $\begin{array}{l}\text { Postnatal } \\
\text { antibiotic } \\
\text { treatment }\end{array}$ & $\begin{array}{l}\text { Gut microbiota } \\
\text { composition } \\
\text { Brain A } \beta \text { deposition } \\
\text { Foxp3+ Treg cells in } \\
\text { blood and brain } \\
\text { Serum and } \\
\text { cerebrospinal fluid } \\
\text { inflammation }\end{array}$ & $\begin{array}{l}\text { Postnatal antibiotic treatment induced } \\
\text { stable perturbations in gut microbiota } \\
\text { diversity, with reduced species } \\
\text { richness and increased representation } \\
\text { of Lachnospiraceae, upregulation of } \\
\text { circulating and brain Foxp3+ Treg cells } \\
\text { and reduced deposition of brain } \\
A \beta \text { amyloid }\end{array}$ & $\begin{array}{l}\text { Gut microbiota may mediate } \\
\text { neuroinflammation through } \\
\text { production of butyrate and } \\
\text { differentiation of T-cells in to } \\
\text { Foxp3+ Treg cells }\end{array}$ \\
\hline
\end{tabular}

Abbreviations: BDNF, brain-derived neurotrophic factor; NMDA, N-methyl-D-aspartic acid; Treg, T regulatory; IVF, in vitro fertilization; NPY, neuropeptide Y.

and Porphyromonadaceae, whose relative abundance was positively correlated with cognitive impairment measured with neuropsychological tests. ${ }^{55}$ In a later case-control study, the same authors found that cognitive performance of elderly patients was negatively correlated with the relative abundance of Enterobacteriaceae and Porphyromonadaceae and positively correlated with the Lactobacillales relative abundance, irrespective of the presence of cirrhosis. ${ }^{56}$ Finally, liver transplantation proved to be able to reduce gut microbiota dysbiosis associated with advanced cirrhosis, with a simultaneous improvement in cognitive symptoms. ${ }^{57}$ The presence of a gut-brain axis modulating cognitive function in gastrointestinal and liver diseases is also supported by the observation that rifaximin administration is associated with cognition improvement in cirrhosis, ${ }^{58}$ and that irritable bowel syndrome, a functional disorder implying mild gut microbiota dysbiosis, is associated with an increased risk of dementia. ${ }^{59}$

Most studies exploring the putative role of gut microbiota in the pathogenesis of dementia did not include metagenomics profiling of fecal microbiota, but were focused on the detection of microbial metabolites in blood or brain tissue samples. For example, $\mathrm{Xu}$ and Wang analyzed public anonymous databases of genetic and metabolic data to identify microbial 
metabolites associated with cognitive decline in AD. ${ }^{60}$ They found that three of them, that is, mannitol, succinic acid and 3,4-dihyfroxybenzeneacetic acid, are particularly overrepresented in subjects with $\mathrm{AD}$, suggesting the presence of a different gut microbiota profile. ${ }^{60}$ In 59 patients with overt dementia or MCI, Andreadou et al demonstrated high serum and cerebrospinal fluid levels of rhamnolipids, representing exotoxins and virulence factors produced by Gram-negative bacteria. ${ }^{61}$ Similarly, the presence of Gramnegative bacteria-derived lipopolysaccharide (LPS) was recently detected in postmortem hippocampal and temporal neocortex tissue extracts from six patients with AD. ${ }^{62}$ These findings allow to hypothesize the presence of a distinct gut microbiota signature in $\mathrm{AD}$, characterized by dysbiosis with overrepresentation of Gram-negative pathogens.

Interestingly, in another study performed on 20 patients and 13 controls, polymerase chain reaction analysis of fecal samples allowed to identify genome sequences from Clostridium spp. specific of patients with AD. ${ }^{63}$ These sequences encoded for NADH:ubiquinone oxidoreductase, an enzyme involved in aromatic amino acid production. ${ }^{63}$ High levels of these amino acids in the brain may induce cell death and neurodegeneration, and thus, the gut microbiota functionality may directly influence the AD physiopathology through this pathway.

A comprehensive microbiota analysis was performed on fecal samples from patients with dementia in only four studies. Araos et $\mathrm{al}^{64}$ used a $16 \mathrm{~S}$ rRNS microbial profiling approach and found an extreme reduction of microbiota biodiversity, particularly in those subjects with colonization with Clostridium difficile. Cattaneo et $\mathrm{al}^{65}$ instead compared the fecal microbiota composition of 40 amyloid-positive patients with cognitive impairment, 33 amyloid-negative patients with cognitive impairment and 10 healthy controls using a quantitative-polymerase chain reaction approach. They found lower abundance of Eubacterium rectale and higher abundance of Escherichia/Shigella in amyloid-positive patients, and these gut microbiota differences were correlated with the systemic inflammatory profile. Thus, the authors hypothesized a role of the gut microbiota in regulating amyloid deposition in the brain through modulation of inflammation. ${ }^{65}$ Vogt et al analyzed fecal samples from 25 patients with AD and 25 controls, demonstrating a reduced representation of Firmicutes and Bifidobacteria and an increased representation of Bacteroidetes in the fecal microbiota of demented patients. ${ }^{66}$ They also showed that the cerebrospinal fluid levels of $\mathrm{AD}$ markers, such as $\mathrm{A} \beta_{42} / \mathrm{A} \beta_{40}$ and YKL-40, were significantly correlated with the relative abundance of
Bacteroides and Blautia in a positive way and of Dialister and Turicibacter in a negative way. ${ }^{66}$ The presence of gut microbiota dysbiosis in patients with $\mathrm{AD}$ was also recently confirmed by Zhuang et al, who analyzed fecal samples from 43 patients with $\mathrm{AD}$ and 43 controls and demonstrated similar alterations, including overexpression of Bacteroides. ${ }^{67}$

Moreover, Qjan et al recently demonstrated that the relative abundance of Bifidobacterium, Butyricicoccus and Clostridium $X I V b$ in gut microbiota was negatively correlated with the presence of cognitive impairment in patients with Parkinson's disease, a neurodegenerative condition often correlated with dementia. ${ }^{68}$

\section{Intervention studies on animals}

Probiotics were administered to animal models of neuroinflammation, AD or vascular dementia in eleven studies, ${ }^{69-79}$ whose results have been summarized in Table 3. In all these studies, the administration of single bacterial taxa or probiotic blend determined reduced decline of cognitive function, measured in mice mainly with the Morris water maze test, which specifically explores spatial memory tasks. Multiple tests of mouse cognitive function were performed in only one study, ${ }^{74}$ where a probiotic blend containing nine bacterial strains was administered to transgenic $\mathrm{AD}$ mice. The probiotic intervention showed improved performance in all the cognitive tests and also reduced anxiety-like behaviors. ${ }^{74}$ From a physiopathologic point of view, probiotic interventions showed improvements, or reduced deterioration, in many other aspects of dementia, including cortical and hippocampal expression of genes involved in neural plasticity and inflammation control, excitatory postsynaptic potentials, activation of molecular pathways protecting against apoptosis (such as BDNF-p13K/Akt), histological signs of cell damage and amyloid deposition, and neurotransmitter and cytokine levels (Table 3). Overall, these experiments support the concept of a gut-brain axis in dementia, modulating brain histology and function through influence in gene expression and inflammation control.

In other six intervention studies, ${ }^{79-84}$ the effects of gut microbiota on animal cognitive function or dementia-related outcomes were explored by administering prebiotics, that is, functional foods or nutrition supplements inducing the selective growth of specific gut microbiota populations. The results of these studies are summarized in Table 4. The presence of a gut-brain axis modulating dementia physiopathology was first demonstrated with the circumstance that urolithins, gut microbiota-derived metabolites from grape seed ellagitannins, can improve $\beta$-amyloid aggregation and 
signs of cognitive impairment in animal models. ${ }^{80,81}$ Then, the administration of other prebiotics, including teasaponin, fructo-oligosaccharides, baicalein and xylo-oligosaccharides, proved effective in preventing the advancement of cognitive symptoms in mouse models of $\mathrm{AD}$ or vascular dementia. ${ }^{79,82-84}$

\section{Intervention studies on humans}

Only four papers reporting results of studies where probiotics were administered to human subjects fulfilled the search criteria. ${ }^{85-88}$ In three of them, healthy volunteers were involved, with a randomized, placebo-controlled study design. ${ }^{85-87}$ Conversely, probiotics were administered to older

Table 3 Summary of animal intervention studies investigating the effects of probiotic formulations on dementia-related outcomes

\begin{tabular}{|c|c|c|c|c|c|}
\hline $\begin{array}{l}\text { First author, } \\
\text { journal, } \\
\text { year (ref) }\end{array}$ & Animal model & Exposure & Duration & $\begin{array}{l}\text { Dementia-related } \\
\text { outcomes measured }\end{array}$ & Main results \\
\hline $\begin{array}{l}\text { Davari, } \\
\text { Neuroscience, 201369 }\end{array}$ & $\begin{array}{l}\text { Rats with } \\
\text { streptozocin-induced } \\
\text { diabetes }\end{array}$ & $\begin{array}{l}\text { Probiotic blend with } \\
\text { Lactobacillus acidophilus, } \\
\text { Bifidobacterium lactis, } \\
\text { Lactobacillus fermentum } \\
\text { vs placebo }\end{array}$ & 2 months & $\begin{array}{l}\text { Spatial learning tasks } \\
\text { (Morris water maze test) } \\
\text { Basic and potentiated } \\
\text { EPSPs in the CAI area of } \\
\text { hippocampus }\end{array}$ & $\begin{array}{l}\text { Improvement in spatial } \\
\text { learning tasks } \\
\text { Maintenance of basic and } \\
\text { potentiated EPSPs (decline } \\
\text { observed in controls) }\end{array}$ \\
\hline $\begin{array}{l}\text { Distrutti, PLoS } \\
\text { One, } 2014^{70}\end{array}$ & $\begin{array}{l}\text { Young and aged male } \\
\text { Wistar rats }\end{array}$ & $\begin{array}{l}\text { VSL\#3 probiotic } \\
\text { blend vs maple syrup } \\
\text { (control) }\end{array}$ & 6 weeks & $\begin{array}{l}\text { EPSPs in dentate } \\
\text { gyrus after long-term } \\
\text { potentiation shock test } \\
\text { Expression of cortical } \\
\text { tissue genes detected by } \\
\text { microarray analysis }\end{array}$ & $\begin{array}{l}\text { Improvement of cortical } \\
\text { expression of genes involved } \\
\text { in inflammation modulation } \\
\text { and neural plasticity (BDNF, } \\
\text { synapsin among others) } \\
\text { Attenuation of the age-related } \\
\text { deficit in EPSPs after long- } \\
\text { term potentiation shock test }\end{array}$ \\
\hline $\begin{array}{l}\text { Liu, Biomed } \\
\text { Res Int, 2015 } 5^{71}\end{array}$ & $\begin{array}{l}\text { Mice with vascular } \\
\text { dementia induced } \\
\text { by a permanent } \\
\text { unilateral right } \\
\text { common carotid } \\
\text { artery occlusion }\end{array}$ & Clostridium butyricum & 6 weeks & $\begin{array}{l}\text { Spatial learning tasks } \\
\text { (Morris water maze test) } \\
\text { Histological signs of } \\
\text { neuronal apoptosis in } \\
\text { hippocampal tissue } \\
\text { BDNF-PI3K/Akt pathway } \\
\text { protein expression }\end{array}$ & $\begin{array}{l}\text { Improvement in spatial } \\
\text { learning tasks } \\
\text { Reduced signs of hippocampal } \\
\text { neuron apoptosis } \\
\text { Activation of BDNF-PI3K/Akt } \\
\text { pathway-related proteins }\end{array}$ \\
\hline $\begin{array}{l}\text { Liang, } \\
\text { Neuroscience, } \\
2015^{72}\end{array}$ & $\begin{array}{l}\text { Sprague Dawley } \\
\text { rats subjected to } \\
\text { restraint stress }\end{array}$ & $\begin{array}{l}\text { Lactobacillus helveticus } \\
\text { NS8 }\end{array}$ & 3 weeks & $\begin{array}{l}\text { Anxiety behaviors and } \\
\text { memory tasks } \\
\text { Plasma cortisol, ACTH } \\
\text { and cytokine levels } \\
\text { BDNF mRNA expression } \\
\text { in prefrontal cortex and } \\
\text { hippocampus } \\
\text { Brain monoamine } \\
\text { neurotransmitters }\end{array}$ & $\begin{array}{l}\text { Reduction of anxiety } \\
\text { behaviors and memory } \\
\text { dysfunction induced by stress } \\
\text { Lower plasma cortisol and } \\
\text { ACTH levels, higher IL-10 } \\
\text { levels } \\
\text { Higher hippocampal BDNF } \\
\text { expression }\end{array}$ \\
\hline $\begin{array}{l}\text { Sun, Brain Res, } \\
2016^{73}\end{array}$ & $\begin{array}{l}\text { Mice with } \\
\text { streptozocin-induced } \\
\text { diabetes subjected } \\
\text { to } 30 \text { minutes of } \\
\text { bilateral common } \\
\text { carotid artery } \\
\text { occlusion }\end{array}$ & C. butyricum & 6 weeks & $\begin{array}{l}\text { Spatial learning tasks } \\
\text { (Morris water maze test) } \\
\text { Hippocampal neuron } \\
\text { damage and apoptosis } \\
\text { Brain expression of Akt, } \\
\text { phospho-Akt, caspase-3 }\end{array}$ & $\begin{array}{l}\text { Attenuation of decline in } \\
\text { spatial learning tasks } \\
\text { Attenuation of hippocampal } \\
\text { neuron apoptosis } \\
\text { Increased expression of } \\
\text { Akt, phosphor-Akt and } \\
\text { caspase-3, limiting apoptosis } \\
\text { in hippocampal neurons }\end{array}$ \\
\hline $\begin{array}{l}\text { Bonfili, Sci Rep, } \\
2017^{74}\end{array}$ & $\begin{array}{l}3 \times T g-A D \text { transgenic } \\
\text { mice with early-stage } \\
\text { Alzheimer's disease }\end{array}$ & $\begin{array}{l}\text { SLAB5 I probiotic } \\
\text { blend containing nine } \\
\text { strains (bifidobacteria, } \\
\text { lactobacilli and } \\
\text { Streptococcus } \\
\text { thermophilus) }\end{array}$ & 4 months & $\begin{array}{l}\text { Multiple tests of } \\
\text { locomotor activity, } \\
\text { recognition memory, } \\
\text { fear-motivated reactions, } \\
\text { anxiety-related behaviors } \\
\text { Amyloid brain deposition } \\
\text { Proteasome activity in } \\
\text { brain homogenates }\end{array}$ & $\begin{array}{l}\text { Reduced decline in } \\
\text { performance at cognitive and } \\
\text { anxiety-related tests } \\
\text { Reduced amyloid } \\
\text { accumulation } \\
\text { Increased expression of } \\
\text { neuronal proteolytic pathways }\end{array}$ \\
\hline
\end{tabular}


Table 3 (Continued)

\begin{tabular}{|c|c|c|c|c|c|}
\hline $\begin{array}{l}\text { First author, } \\
\text { journal, } \\
\text { year (ref) }\end{array}$ & Animal model & Exposure & Duration & $\begin{array}{l}\text { Dementia-related } \\
\text { outcomes measured }\end{array}$ & Main results \\
\hline $\begin{array}{l}\text { Nimgampalle, } \\
\text { J Clin Diagn Res, } \\
2017^{75}\end{array}$ & $\begin{array}{l}\text { Albino rats with } \\
\text { D-galactose induced } \\
\text { Alzheimer's disease }\end{array}$ & Lactobacillus plantarum & 2 months & $\begin{array}{l}\text { Spatial learning tasks } \\
\text { (Morris water maze test) } \\
\text { Gross behavioral activity } \\
\text { Brain neuron } \\
\text { degeneration } \\
\text { Brain acetylcholine level }\end{array}$ & $\begin{array}{l}\text { Improved spatial learning } \\
\text { tasks and gross behavior } \\
\text { activity } \\
\text { Reduced neuron degeneration } \\
\text { Maintenance of acetylcholine } \\
\text { levels }\end{array}$ \\
\hline $\begin{array}{l}\text { Kobayashi, Sci } \\
\text { Rep, } 2017^{76}\end{array}$ & $\begin{array}{l}\text { ddY mice with } A \beta \\
\text { injection-induced } \\
\text { Alzheimer's disease }\end{array}$ & $\begin{array}{l}\text { Bifidobacterium breve } \\
\text { strain Al }\end{array}$ & 6 days & $\begin{array}{l}\text { Alternation behavior in } \\
\text { Y maze test } \\
\text { Latency time in passive } \\
\text { avoidance test } \\
\text { Hippocampal neuron } \\
\text { gene expression }\end{array}$ & $\begin{array}{l}\text { Prevention of decline } \\
\text { in cognitive dysfunction } \\
\text { measured with alternation } \\
\text { behavior and passive } \\
\text { avoidance test } \\
\text { Reversal of A } \beta \text {-induced } \\
\text { change in hippocampal } \\
\text { gene expression } \\
\text { (reduced expression of } \\
\text { proinflammatory genes) }\end{array}$ \\
\hline $\begin{array}{l}\text { Musa, J Dairy } \\
\text { Res, 201777 }\end{array}$ & $\begin{array}{l}\text { ICR mice with } \\
\text { neuroinflammation } \\
\text { induced by } \\
\text { lipopolysaccharide } \\
\text { brain injection }\end{array}$ & $\begin{array}{l}\text { Lactic acid bacteria } \\
\text { probiotic blend } \\
\text { derived from fresh } \\
\text { cow milk }\end{array}$ & 28 days & $\begin{array}{l}\text { Spatial learning tasks } \\
\text { (Morris water maze test) } \\
\text { Acetylcholine, antioxidant } \\
\text { and proinflammatory } \\
\text { cytokine levels in brain } \\
\text { lysate }\end{array}$ & $\begin{array}{l}\text { Attenuation of } \\
\text { neuroinflammation-induced } \\
\text { decline in spatial learning tasks } \\
\text { Increase of acetylcholine } \\
\text { and antioxidant brain levels, } \\
\text { reduction of proinflammatory } \\
\text { cytokines }\end{array}$ \\
\hline $\begin{array}{l}\text { Chunchai, J } \\
\text { Neuroinflammation, } \\
2018^{78}\end{array}$ & $\begin{array}{l}\text { Male Wistar rats fed } \\
\text { with high-fat diet- } \\
\text { induced dementia }\end{array}$ & Lactobacillus paracasei & 12 weeks & $\begin{array}{l}\text { Spatial learning tasks } \\
\text { (Morris water maze test) } \\
\text { Microglial activation } \\
\text { Brain mitochondrial } \\
\text { function } \\
\text { Hippocampal plasticity, } \\
\text { oxidative stress, } \\
\text { apoptosis }\end{array}$ & $\begin{array}{l}\text { Improvement of high-fat diet- } \\
\text { induced impairment in spatial } \\
\text { learning tasks } \\
\text { Reduced microglial activation } \\
\text { Improved brain mitochondrial } \\
\text { dysfunction } \\
\text { Restored hippocampal } \\
\text { plasticity and reduced } \\
\text { oxidative stress and apoptosis }\end{array}$ \\
\hline $\begin{array}{l}\text { Athari Nik Azm, } \\
\text { Appl Physiol Nutr } \\
\text { Metab, } 2018^{79}\end{array}$ & $\begin{array}{l}\text { Mice with } A \beta \\
\text { injection-induced } \\
\text { Alzheimer's disease }\end{array}$ & $\begin{array}{l}\text { Probiotic blend } \\
\text { with L. acidophilus, } \\
\text { L. fermentum, B. lactis, } \\
\text { Bifodobacterium longum }\end{array}$ & 8 weeks & $\begin{array}{l}\text { Spatial learning tasks } \\
\text { (Morris water maze test) } \\
\text { Hippocampal oxidative } \\
\text { stress biomarkers }\end{array}$ & $\begin{array}{l}\text { Reduced decline in spatial } \\
\text { learning tasks } \\
\text { Improvement in oxidative } \\
\text { stress biomarkers } \\
\text { (malondialdehyde, superoxide } \\
\text { dismutase) }\end{array}$ \\
\hline
\end{tabular}

Abbreviations: ACTH, adrenocorticotropic hormone; BDNF, brain-derived neurotrophic factor; EPSP, excitatory postsynaptic potential; IL-I0, interleukin- I0.

persons with dementia in only one small study, but cognitive outcomes were not assessed. ${ }^{88}$

In the earliest of these intervention studies, ${ }^{85} 132$ volunteers aged on average 61.8 years were randomized to receive milk drink containing Lactobacillus casei Shirota or milk drink alone, in order to verify the effect on mood symptoms. The intervention group did actually experience improved mood, but unexpectedly exhibited decreased performance in memory tasks. ${ }^{85}$ On the other hand, Allen et al showed that the administration of Bifidobacterium longum 1,714 to 22 healthy young volunteers induced subtle, but significant, improvements in hippocampus-dependent visuospatial memory tasks and electroencephalographic profile. ${ }^{86}$ However, the same research group later reported that the administration of Lactobacillus rhamnosus to 29 young male volunteers did not improve electroencephalographic parameters and cognitive outcomes, including visuospatial memory and attention switching tasks, after an 8-week treatment. ${ }^{87}$

\section{Discussion}

Most of the existing research exploring the possible interaction between gut microbiota composition and cognitive 
Table 4 Summary of animal intervention studies investigating the effects of prebiotic formulations or functional foods on dementiarelated outcomes

\begin{tabular}{|c|c|c|c|c|c|}
\hline $\begin{array}{l}\text { First author, } \\
\text { journal, } \\
\text { year (ref) }\end{array}$ & Animal model & Exposure & Duration & $\begin{array}{l}\text { Dementia-related } \\
\text { outcomes measured }\end{array}$ & Main results \\
\hline $\begin{array}{l}\text { Wang, Mol } \\
\text { Nutr Food } \\
\text { Res, } 2015^{80}\end{array}$ & $\begin{array}{l}\text { Male Sprague } \\
\text { Dawley rats }\end{array}$ & $\begin{array}{l}\text { Grape seed polyphenol } \\
\text { extract }\end{array}$ & II days & $\begin{array}{l}\text { Brain concentration of } \\
\text { phenolic acids generated } \\
\text { by gut microbiota } \\
\text { metabolism of grape seed } \\
\text { anthocyanidins } \\
\text { In vitro } \beta \text {-amyloid } \\
\text { aggregation }\end{array}$ & $\begin{array}{l}\text { Elevated phenolic compound } \\
\text { concentrations in the brain } \\
\text { In vitro inhibition of } \beta \text {-amyloid } \\
\text { aggregation induced by the } \\
\text { same phenolic compound } \\
\text { concentrations }\end{array}$ \\
\hline $\begin{array}{l}\text { Yuan, ACS } \\
\text { Chem } \\
\text { Neurosci, } \\
2016^{81}\end{array}$ & $\begin{array}{l}\text { Transgenic } \\
\text { Caenorhabditis } \\
\text { elegans with } \\
\text { AD induced by } \\
\text { brain } \beta \text {-amyloid } \\
\text { injection }\end{array}$ & $\begin{array}{l}\text { Pomegranate extracts } \\
\text { containing ellagitannins; } \\
\text { extracts containing } \\
\text { urolithins (gut } \\
\text { microbiota-derived } \\
\text { ellagitannin metabolites) }\end{array}$ & 20 hours & $\begin{array}{l}\text { Survival and speed of } \\
\text { mobility decline }\end{array}$ & $\begin{array}{l}\text { Reduced decline of mobility in } \\
\text { worms treated with urolithins, } \\
\text { but not in worms treated with } \\
\text { pomegranate extracts } \\
\text { No effect on survival time }\end{array}$ \\
\hline $\begin{array}{l}\text { Wang, Sci Rep, } \\
2017^{82}\end{array}$ & $\begin{array}{l}\text { C57BL/6J male } \\
\text { mice with high- } \\
\text { fat diet-induced } \\
\text { obesity and } \\
\text { cognitive decline }\end{array}$ & $\begin{array}{l}\text { Teasaponin (terpenic } \\
\text { glycoside derived } \\
\text { from tea) }\end{array}$ & 6 weeks & $\begin{array}{l}\text { Object recognition } \\
\text { performance } \\
\text { Recognition memory } \\
\text { assessed with } \\
\text { discrimination index } \\
\text { BDNF levels in the } \\
\text { hippocampus }\end{array}$ & $\begin{array}{l}\text { Reduced decline of recognition } \\
\text { memory and object recognition } \\
\text { performance } \\
\text { Decreased decline in BDNF } \\
\text { expression in the hippocampus }\end{array}$ \\
\hline $\begin{array}{l}\text { Chen, } \\
\text { Front Aging } \\
\text { Neurosci, 201783 }\end{array}$ & $\begin{array}{l}\text { Rats with } \\
\text { D-galactose } \\
\text { and } \beta \text {-amyloid } \\
\text { administration- } \\
\text { induced AD }\end{array}$ & $\begin{array}{l}\text { Fructo-oligosaccharides } \\
\text { from Morinda officinalis }\end{array}$ & 4 weeks & $\begin{array}{l}\text { Spatial learning tasks } \\
\text { (Morris water maze test) } \\
\text { Brain levels of cytokines, } \\
\text { antioxidants, and } \\
\text { neurotransmitters } \\
\text { Brain tissue histology, } \\
\text { including amyloid deposition }\end{array}$ & $\begin{array}{l}\text { Improved spatial learning tasks } \\
\text { Improved oxidative stress, } \\
\text { inflammation and synthesis of } \\
\text { neurotransmitters } \\
\text { Reduced neuronal apoptosis } \\
\text { and amyloid deposition }\end{array}$ \\
\hline $\begin{array}{l}\text { Gao, ACS } \\
\text { Chem Neurosci, } \\
2018^{84}\end{array}$ & $\begin{array}{l}\text { Transgenic } \\
\text { senescence- } \\
\text { accelerated } \\
\text { mouse prone } 8 \\
\text { (SAMP8) }\end{array}$ & $\begin{array}{l}\text { Baicalein (flavonoid } \\
\text { derived from } \\
\text { Scutellariae baicalensis } \\
\text { Georgi roots) }\end{array}$ & 4 weeks & $\begin{array}{l}\text { Spatial learning tasks } \\
\text { (Morris water maze test) } \\
\text { Olfactory memory } \\
\text { Novel object recognition } \\
\text { ability } \\
\text { Brain cortical levels of } \\
\text { proinflammatory cytokines }\end{array}$ & $\begin{array}{l}\text { Improved spatial learning } \\
\text { abilities, olfactory memory and } \\
\text { object recognition memory } \\
\text { Reduced expression of } \\
\text { proinflammatory cytokines in } \\
\text { the brain cortex }\end{array}$ \\
\hline $\begin{array}{l}\text { Chunchai, J } \\
\text { Neuroinflammation, } \\
2018^{78}\end{array}$ & $\begin{array}{l}\text { Male Wistar rats } \\
\text { fed with high-fat } \\
\text { diet-induced } \\
\text { dementia }\end{array}$ & $\begin{array}{l}\text { Xylo-oligosaccharide } \\
\text { formulas }\end{array}$ & 12 weeks & $\begin{array}{l}\text { Spatial learning tasks } \\
\text { (Morris water maze test) } \\
\text { Microglial activation } \\
\text { Brain mitochondrial } \\
\text { function } \\
\text { Hippocampal plasticity, } \\
\text { oxidative stress, apoptosis }\end{array}$ & $\begin{array}{l}\text { Improvement of impairment in } \\
\text { spatial learning tasks } \\
\text { Reduced microglial activation } \\
\text { Improved brain mitochondrial } \\
\text { dysfunction } \\
\text { Restored hippocampal } \\
\text { plasticity, reduced oxidative } \\
\text { stress and apoptosis }\end{array}$ \\
\hline
\end{tabular}

Abbreviations: AD, Alzheimer's disease; BDNF, brain-derived neurotrophic factor.

function has been performed in animal models. Human studies were mostly performed in subjects with an established diagnosis of dementia, and outside the geriatric constructs of cognitive frailty and MCI. In this context, there is a substantial gap between animal studies, indicating an established involvement of gut microbiota in modulating several physiopathologic aspects of dementia, and clinical studies, performed mainly on small samples and lacking a comprehensive profiling of gut microbiota composition and functionality. ${ }^{89}$

The reasons of this gap are not completely clear. The reduced availability of metagenomics lab research platforms in clinical contexts represents probably the main one. Despite the massive boost of scientific literature on gut microbiota, 
next-generation sequencing analyses of fecal samples for microbial profiling have entered clinical research only recently, and many aspects of the gut microbiota function in modulation of human diseases are still poorly investigated. ${ }^{24}$ Additionally, research on human subjects with cognitive impairment or dementia may imply several critical issues, from the ethical and methodological point of view, preventing their participation in research protocols with several laboratory analyses. Older patients with dementia may also have complex clinical pictures, with multimorbidity, polypharmacy, functional dependence, malnutrition, constipation and geriatric syndromes, which are very difficult to consider as covariates in microbiome research. ${ }^{24}$ Finally, dementia has long been considered as an "organ" disease, while modern evidence supports its definition as a "systemic disease", where peripheral physiopathologic phenomena may also have an important role in its development and course. ${ }^{90}$

Therefore, the knowledge of the physiopathologic role of gut microbiota composition in modulating the onset and clinical course of chronic diseases is much more established for other neuropsychiatric disorders such as Parkinson disease. ${ }^{91,92}$ Age-related degenerative diseases, however, share several physiopathologic pathways, ${ }^{93}$ so that a role of gut microbiota in the development and clinical course of AD is highly plausible, even if not yet comprehensively investigated. In fact, studies exploring the possible contribution of infective agents in AD onset have mainly focused on the central nervous system or systemic infections, but not on microbiota. ${ }^{94}$ A synthetic graphical overview of the factors possibly involved in the dementia "gut-brain axis" is presented in Figure 2.

Several authors have, however, underlined the circumstance that many gut bacterial taxa can produce amyloid proteins. ${ }^{95,96}$ These proteins could be phagocytized in enteric immune system cells and then delivered to the central nervous system, ${ }^{95}$ or directly enter the systemic circulation as a consequence of a "leaky gut", that is, altered mucosal permeability induced by microbiota dysbiosis. ${ }^{96}$ Diet could also have a relevant influence in inducing gut microbiota alterations predisposing to amyloid production and delivery to the brain. ${ }^{97}$ Bacterial amyloid proteins could then influence $\beta$-amyloid deposition in the brain with two different pathways: induction of neuroinflammation or molecular mimicry, that is, misfolding of neuronal proteins through cross-seeding. ${ }^{98}$

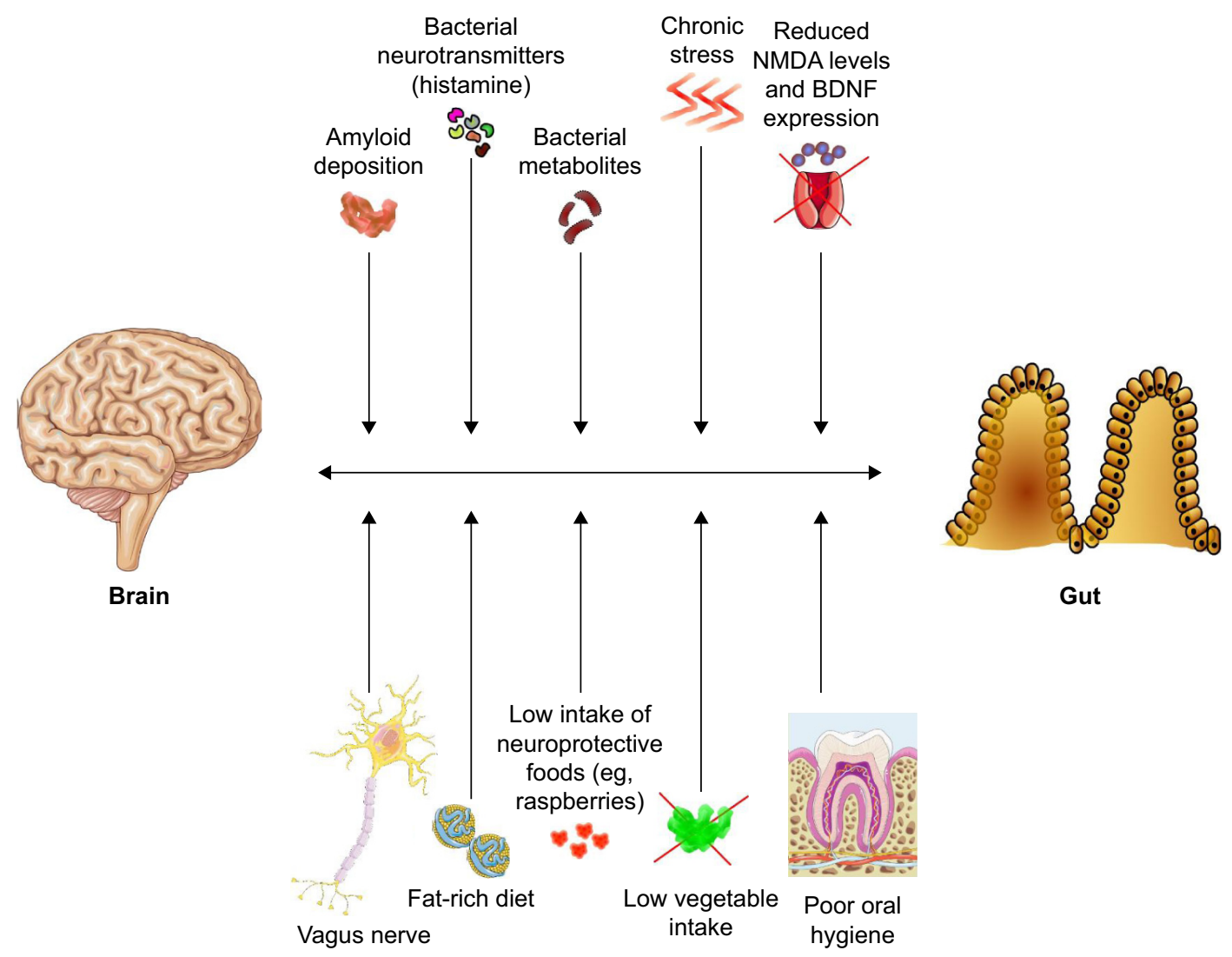

Figure 2 Synthetic graphical overview of the possible factors and mechanisms involved in the putative "gut-brain axis" of dementia physiopathology. Abbreviations: BDNF, brain-derived neurotrophic factor; NMDA, N-methyl-D-aspartic acid. 
In aging individuals, several stressors, such as dietary variations, acute or chronic illness, gastrointestinal infections, constipation and pharmacotherapy, can contribute to induce gut microbiota dysbiosis. ${ }^{24,31,99,100}$ This phenomenon, especially when associated with microbiota composition instability, can promote systemic inflammation through the absorption of bacterial toxins such as LPS. The resulting proinflammatory cytokine production can result in brain microglia activation, promoting neuroinflammation, neuronal apoptosis and $\beta$-amyloid deposition. ${ }^{101}$ Interestingly, some gut bacteria, such as cyanobacteria, can produce neurotoxins (saxitoxin and anatoxin- $\alpha$ ) that may be involved in neurodegeneration as well. ${ }^{102}$

Gut microbiota can influence the physiopathology of AD also through the synthesis of metabolites that, once absorbed in the systemic circulation, can modulate neural function. ${ }^{103}$ These metabolites, extensively reviewed by Alkasir et al, may have either neuroprotective or neurotoxic effects. ${ }^{104}$ For example, Lactobacillus, Lactococcus, Streptococcus and Enterococcus may produce histamine, which acts as a neurotransmitter and an important modulator of neuroinflammation through reduction of tumor necrosis factor-alpha expression in the brain. ${ }^{103,104}$ Similarly, other bacterial taxa, including Bacillus, Lactobacillus and Bifidobacterium, are able to synthesize neurotransmitters involved in memory and learning function regulation, such as gamma-aminobutyric acid, serotonin, norepinephrine and acetylcholine. ${ }^{103,104}$ Clostridium spp. may also produce indole-3-propionic acid, a relevant antioxidant for neurons. ${ }^{103,104}$

Conversely, $\beta$ - $N$-methylamino-alanine, a metabolite produced by cyanobacteria, has been linked with intraneuronal protein misfolding, and thus could contribute to $\beta$-amyloid deposition. ${ }^{102}$ Metabolites derived from gut microbiota tryptophan metabolism may also promote neuronal oxidative stress, cell death, tau phosphorylation and tangle formation. ${ }^{103}$

Among the most interesting putative microbial mediators regulating brain function, SCFAs, and particularly butyrate, derived from carbohydrate fermentation, have demonstrated a strong systemic and neural anti-inflammatory activity, promoting also the synthesis of several neurotransmitters and hormones. ${ }^{104,105}$ In fact, a large body of scientific literature has demonstrated that the administration of butyrate to experimental mouse models of neurological diseases resulted in significant modulation of gene expression and improvement in molecular pathways of neuron damage. ${ }^{105}$ Interestingly, gut microbiota-derived butyrate has been recently proposed as one of the main mediators of a putative gut-muscle axis regulating the onset of physical frailty and sarcopenia in older individuals. ${ }^{34}$

The importance of the microbiota in modulating systemic inflammation and neuroinflammation leading to the development and progression of AD has been also underlined by the circumstance that $\mathrm{AD}$ patients may have oral microbiota overgrowth. This finding allowed to hypothesize a role of periodontitis in the pathogenesis of AD. ${ }^{106,107}$

Other authors have also emphasized the possible role of the vagal nerve in transducing gut microbiota signals to the brain. ${ }^{108,109}$ This mechanism has been particularly studied in situations of stress, where gut microbiota dysbiosis can promote neurohormonal alterations sustaining inflammation and promoting apoptosis. ${ }^{108,109}$ These pathways may represent the physiopathologic substrate linking irritable bowel syndrome-associated dysbiosis with the risk of dementia. ${ }^{56,110}$

The role of diet in these mechanisms is still poorly understood, but probably of utmost importance. Dietary patterns are strongly involved in the risk of developing AD and in its course, once the disease has established. ${ }^{111}$ Diets with patterns similar to Mediterranean and Dietary Approaches to Stop Hypertension diets have been associated with a reduced risk of $\mathrm{AD}$ and milder disease course, while Western-style diet represents an important risk factor. ${ }^{111}$ Among nutrients, saturated fatty acid consumption is associated with increased risk of $\mathrm{AD}$, while an adequate dietary intake of polyphenols, unsaturated fatty acids and vitamins $\mathrm{A}, \mathrm{E}$ and $\mathrm{C}$ may have a protective effect against the development of dementia. ${ }^{11,112}$ Interestingly, diet represents one of the main environmental factors shaping gut microbiota composition. ${ }^{24}$ The variety and nutrient composition of diet, and particularly long-term dietary habits, may, in fact, influence the gut microbiota biodiversity and shape the overall microbial community. ${ }^{113,114}$ For example, in healthy adults, dietary habits were significantly associated with specific gut microbiota composition patterns, the so-called "enterotypes". ${ }^{115}$ Similarly, in older individuals, the variety and pattern of food consumption were associated with a different trend toward gut microbiota dysbiosis. $^{27}$

As suggested by the findings of studies summarized in Table 4, gut microbiota may be strongly involved in the association between diet and dementia development. Healthy dietary habits promote a gut microbiota composition with anti-inflammatory activity. ${ }^{116}$ Conversely, high-fat diets may promote gut microbiota dysbiosis, and thus support systemic inflammation. ${ }^{117}$ Moreover, healthy gut microbiota may be fundamental for the transformation of dietary nutrients 
into active compounds exerting beneficial effects on the brain. Polyphenols represent a prototype of this possible mechanism. ${ }^{118}$ In fact, red raspberry-derived anthocyanins and ellagitannins need specific gut microbiota metabolism to be transformed into urolithins, ${ }^{119}$ which may exert important neuroprotective effects. ${ }^{80,81}$ Similarly, curcumin has recently emerged as a promising modulator of the gut microbiota, showing neuroprotective effects. ${ }^{120}$ In fact, its administration is able to induce increased expression of taxa with anti-inflammatory properties in gut microbiota, attenuating the systemic LPS absorption associated with Western-style diet. ${ }^{120}$ Moreover, curcumin metabolites produced by the microbiota itself can exert independent antioxidant activity, particularly against the central nervous system, ${ }^{121}$ and inhibit tau protein aggregation in vitro. ${ }^{122}$ In an open-label intervention study, curcumin administration to patients with MCI resulted in improvement in cognitive symptoms, making it a very promising target for novel drug development. ${ }^{123}$

Another critical issue of the existing studies on the microbiota-dementia relationship is the circumstance that most of them have been performed on animal models or patients with AD type of dementia. Very few of them have been performed in the context of vascular dementia, and none on other types of dementia, despite the clinical and physiopathologic relevance of this classification. However, the gut-brain axis also mediates the neuroinflammatory response after a vascular injury, such as ischemic stroke. ${ }^{124}$ Additionally, diabetes mellitus and obesity, which are among the main conditions predisposing to vascular dementia, are both associated with gut microbiota alterations and/or dysbiosis. ${ }^{125,126}$ Thus, the gut microbiota may also be involved in vascular cognitive impairment, mainly through modulation of local neural and systemic inflammation and insulin sensitivity. ${ }^{127}$

The results of animal intervention studies (Tables 3 and 4) support the assumption that manipulation of gut microbiota can improve cognitive function. This is a very promising field of preventive and therapeutic intervention, ${ }^{125,128}$ although the few human studies performed up to date have given disappointing results. ${ }^{85-87}$ However, there is increasing evidence indicating that some cerebral functions, and particularly mood and anxiety, can be ameliorated in subjects with psychiatric conditions by the administration of probiotics. ${ }^{129}$ The word "psychobiotics" has been coined to design this specific function of probiotics. ${ }^{130}$ More studies are needed in the future to assess the effects of these preparations on cognitive functions of both healthy individuals and older patients with dementia. ${ }^{125,130}$

\section{Conclusion}

The existence of a gut-brain axis involved in dementia is supported by several observational and intervention studies performed in animal models. As such, a physiopathologic role of gut microbiota alterations in cognitive frailty, MCI and dementia of older people has been hypothesized by many authors, particularly for AD. However, very few investigators have explored this hypothesis with clinical studies. Gut microbiota modulation represents a very interesting area of research for developing novel preventive or curative strategies against cognitive impairment, but, at the current state of the art, no recommendations for clinical practice can be made.

\section{Acknowledgment}

Part of the images is distributed under Creative Commons Licence and can be freely available at the following links: https://smart.servier.com/131 ${ }^{131}$ https://pixabay.com. ${ }^{132}$

\section{Author contributions}

Conception and design of the work: Andrea Ticinesi, Antonio Nouvenne, Fulvio Lauretani, and Tiziana Meschi. Acquisition of data: Andrea Ticinesi, Antonio Nouvenne, and Beatrice Prati. Data analysis: Andrea Ticinesi, Antonio Nouvenne, and Beatrice Prati. Interpretation of data for the work: Andrea Ticinesi, Claudio Tana, and Fulvio Lauretani. Manuscript drafting: Andrea Ticinesi and Claudio Tana. Revision of the manuscript for important content: Fulvio Lauretani and Tiziana Meschi. All authors contributed toward data analysis, drafting and revising the paper and agree to be accountable for all aspects of the work.

\section{Disclosure}

The authors report no conflicts of interest in this work.

\section{References}

1. Kelaiditi E, Cesari M, Canevelli M, et al. Cognitive frailty: rational and definition from an (I.A.N.A./I.A.G.G.) international consensus group. J Nutr Health Aging. 2013;17(9):726-734.

2. Panza F, Seripa D, Solfrizzi V, et al. Targeting cognitive frailty: clinical and neurobiological roadmap for a single complex phenotype. J Alzheimers Dis. 2015;47(4):793-813.

3. Panza F, Lozupone M, Solfrizzi V, et al. Different cognitive frailty models and health- and cognitive-related outcomes in older age: from epidemiology to prevention. J Alzheimers Dis. 2018;62(3):993-1012.

4. Sugimoto T, Sakurai T, Ono R, et al. Epidemiological and clinical significance of cognitive frailty: a mini review. Ageing Res Rev. 2018; $44: 1-7$

5. Clegg A, Young J, Iliffe S, Rikkert MO, Rockwood K. Frailty in elderly people. Lancet. 2013;381(9868):752-762.

6. Feng L, Nyunt MS, Gao Q, et al. Physical frailty, cognitive impairment, and the risk of neurocognitive disorder in the Singapore Longitudinal Ageing Study. J Gerontol A Biol Sci Med Sci. 2017;72(3):369-375. 
7. Solfrizzi V, Scafato E, Lozupone M, et al. Additive role of a potentially reversible cognitive frailty model and inflammatory state on the risk of disability: The Italian Longitudinal Study on Aging. Am J Geriatr Psychiatry. 2017;25(11):1236-1248.

8. Vella Azzopardi R, Beyer I, Vermeiren S, et al. Increasing use of cognitive measures in the operational definition of frailty - a systematic review. Ageing Res Rev. 2018;43:10-16.

9. Lauretani F, Meschi T, Ticinesi A, Maggio M. "Brain-muscle loop" in the fragility of older persons: from pathophysiology to new organizing models. Aging Clin Exp Res. 2017;29(6):1305-1311.

10. Fougère B, Daumas $M$, Lilamand $M$, et al. Association between frailty and cognitive impairment: cross-sectional data from Toulouse frailty day hospital. J Am Med Dir Assoc. 2017;18(11):990.e1-990.e5.

11. Montero-Odasso MM, Barnes B, Speechley M, et al. Disentangling cognitive-frailty: results from the gait and brain study. J Gerontol A Biol Sci Med Sci. 2016;71(11):1476-1482.

12. Petersen RC, Lopez O, Armstrong MJ, et al. Practice guideline update summary: mild cognitive impairment: report of the Guideline Development, Dissemination, and Implementation Subcommittee of the American Academy of Neurology. Neurology. 2018;90(3):126-135.

13. Roppolo M, Mulasso A, Rabaglietti E. Cognitive frailty in Italian community-dwelling older adults: prevalence rate and its association with disability. J Nutr Health Aging. 2017;21(6):631-636.

14. Shimada $H$, Makizako $H$, Lee $S$, et al. Impact of cognitive frailty on daily activities in older persons. J Nutr Health Aging. 2016;20(7):729-735.

15. Rietman ML, van der ADL, van Oostrom SH, et al. The association between BMI and different frailty domains: a U-shaped curve? J Nutr Health Aging. 2018;22(1):8-15.

16. Doi T, Shimada H, Makizako H, et al. Mild cognitive impairment, slow gait, and risk of disability: a prospective study. J Am Med Dir Assoc. 2015;16(12):1082-1086.

17. Solfrizzi V, Scafato E, Seripa D, et al. Reversible cognitive frailty, dementia, and all-cause mortality. The Italian Longitudinal Study on Aging. J Am Med Dir Assoc. 2017;18(1):89.e1-89.e8.

18. Yu R, Morley JE, Kwok T, Leung J, Cheung O, Woo J. The effects of combinations of cognitive impairment and pre-frailty on adverse outcomes from a prospective community-based cohort study of older Chinese people. Front Med. 2018;5:50.

19. Liu Z, Han L, Gahbauer EA, Allore HG, Gill TM. Joint trajectories of cognition and frailty and associated burden of patient-reported outcomes. J Am Med Dir Assoc. 2018;19(4):304-309.

20. Chye L, Wei K, Nyunt MSZ, Gao Q, Wee SL, Tp N. Strong relationship between malnutrition and cognitive frailty in the Singapore Longitudinal Ageing Studies (SLAS-1 and SLAS-2). J Prev Alzheimers Dis. 2018 5(2):142-148.

21. Liu L-K, Lee W-J, Wu Y-H, et al. Cognitive frailty and its association with all-cause mortality among community-dwelling older adults in Taiwan: results from I-Lan Longitudinal Aging Study. Rejuvenation Res. Epub 2018 Apr 12.

22. Ruan Q, D’Onofrio G, Sancarlo D, et al. Emerging biomarkers and screening for cognitive frailty. Aging Clin Exp Res. 2017;29(6):1075-1086.

23. Panza F, Lozupone M, Solfrizzi V, et al. Cognitive frailty: a potential target for secondary prevention of dementia. Expert Opin Drug Metab Toxicol. 2017;13(10):1023-1027.

24. Schmidt TSB, Raes J, Bork P. The human gut microbiome: from association to modulation. Cell. 2018;172(6):1198-1215.

25. Marchesi JR, Adams DH, Fava F, et al. The gut microbiota and host health: a new clinical frontier. Gut. 2016;65(2):330-339.

26. Vaiserman AM, Koliada AK, Marotta F. Gut microbiota: a player in aging and a target for anti-aging intervention. Ageing Res Rev. 2017;35: 36-45.

27. Claesson MJ, Jeffery IB, Conde S, et al. Gut microbiota composition correlates with diet and health in the elderly. Nature. 2012;488(7410): $178-184$

28. Jeffery IB, Lynch DB, O'Toole PW. Composition and temporal stability of the gut microbiota in older persons. ISME J. 2016;10(1): $170-182$
29. Jackson MA, Jeffery IB, Beaumont M, et al. Signatures of early frailty in the gut microbiota. Genome Med. 2016;8:8.

30. Maffei VJ, Kim S, Blanchard E, et al. Biological aging and the human gut microbiota. J Gerontol A Biol Sci Med Sci. 2017;72(11):1474-1482.

31. Ticinesi A, Milani C, Lauretani F, et al. Gut microbiota composition is associated with polypharmacy in elderly hospitalized patients. Sci Rep. 2017;7(1):11102.

32. Haran JP, Bucci V, Dutta P, Ward D, Mccormick B. The nursing home elder microbiome stability and associations with age, frailty, nutrition and physical location. J Med Microbiol. 2018;67(1):40-51.

33. di Sabatino A, Lenti MV, Cammalleri L, Corazza GR, Pilotto A. Frailty and the gut. Dig Liver Dis. Epub 2018 Mar 16.

34. Ticinesi A, Lauretani F, Milani C, et al. Aging gut microbiota at the cross-road between nutrition, physical frailty, and sarcopenia: is there a gut-muscle axis? Nutrients. 2017;9(12):1303.

35. Grosicki GJ, Fielding RA, Lustgarten MS. Gut microbiota contribute to age-related changes in skeletal muscle size, composition, and function: biological basis for a gut-muscle axis. Calcif Tissue Int. 2018;102(4): 433-442.

36. Picca A, Fanelli F, Calvani R, et al. Gut dysbiosis and muscle aging: searching for novel targets against sarcopenia. Mediators Inflamm. 2018; 2018:7026198.

37. Bonaz BL, Bernstein CN. Brain-gut interactions in inflammatory bowel disease. Gastroenterology. 2013;144(1):36-49.

38. Bajaj JS. The role of microbiota in hepatic encephalopathy. Gut Microbes. 2014;5(3):397-403.

39. Rieder R, Wisniewski PJ, Alderman BL, Campbell SC. Microbes and mental health: a review. Brain Behav Immun. 2017;66:9-17.

40. Calvani R, Picca A, Lo Monaco MR, Landi F, Bernabei R, Marzetti E. Of microbes and minds: a narrative review on the second brain aging. Front Med. 2018;5:53

41. Scott KA, Ida M, Peterson VL, et al. Revisiting Metchnikoff: age-related alterations in microbiota-gut-brain axis in the mouse. Brain Behav Immun. 2017;65:20-32.

42. Sadler R, Singh V, Benakis C, et al. Microbiota differences between commercial breeders impacts the post-stroke immune response. Brain Behav Immun. 2017;66:23-30.

43. Shen L, Liu L, Ji HF. Alzheimer's disease histological and behavioral manifestations in transgenic mice correlate with specific gut microbiome state. J Alzheimers Dis. 2017;56(1):385-390.

44. Bauerl C, Collado MC, Diaz Cuevas A, Vina J, Perez Martinez G. Shifts in gut microbiota composition in an APP/PSS1 transgenic mouse model of Alzheimer's disease during lifespan. Lett Appl Microbiol. Epub 2018 Mar 25.

45. Park J-Y, Choi J, Lee Y, et al. Metagenome analysis of bodily microbiota in a mouse model of Alzheimer disease using bacteria-derived membrane vesicles in blood. Exp Neurobiol. 2017;26(6):369-379.

46. Brandscheid C, Schuck F, Reinhardt S, et al. Altered gut microbiome composition and tryptic activity of the $5 \times \mathrm{xFAD}$ Alzheimer's mouse model. J Alzheimers Dis. 2017;56(2):775-788.

47. Zhang L, Wang Y, Xiayu X, et al. Altered gut microbiota in a mouse model of Alzheimer's disease. J Alzheimers Dis. 2017;60(4):1241-1257.

48. Sanguinetti E, Collado MC, Marrachelli VG, et al. Microbiomemetabolome signatures in mice genetically prone to develop dementia, fed a normal or fatty diet. Sci Rep. 2018;8(1):4907.

49. Sc W, Cao ZS, Chang KM, Juang JL. Intestinal microbial dysbiosis aggravates the progression of Alzheimer's disease of Drosophila. Nat Comm. 2017;8:24.

50. Harach T, Marungruang N, Duthilleul N, et al. Reduction of Abeta amyloid pathology in APPPS1 transgenic mice in the absence of gut microbiota. Sci Rep. 2017;7:41802.

51. Minter MR, Zhang C, Leone V, et al. Antibiotic-induced perturbations in gut microbial diversity influences neuro-inflammation and amyloidosis in a murine model of Alzheimer's disease. Sci Rep. 2016;6(1):30028.

52. Fröhlich EE, Farzi A, Mayerhofer R, et al. Cognitive impairment by antibiotic-induced gut dysbiosis: analysis of gut microbiota-brain communication. Brain Behav Immun. 2016;56:140-155. 
53. Cui M, Xiao H, Li Y, et al. Total abdominal irradiation exposure impairs cognitive function involving miR-34a-5p/BDNF axis. Biochim Biophys Acta. 1863;2017:2333-2341.

54. Minter MR, Hinterleitner R, Meisel M, et al. Antibiotic-induced perturbations in microbial diversity during post-natal development alters amyloid pathology in an aged APPSWE/PS1 1 E9 murine model of Alzheimer's disease. Sci Rep. 2017;7(1):10411.

55. Bajaj JS, Ridlon JM, Hylemon PB, et al. Linkage of gut microbiome with cognition in hepatic encephalopathy. Am J Physiol Gastrointest Liver Physiol. 2012;302(1):G168-G175.

56. Bajaj JS, Ahluwalia V, Steinberg JL, et al. Elderly patients have an altered gut-brain axis regardless of the presence of cirrhosis. Sci Rep. 2016;6(1):38481.

57. Bajaj JS, Fagan A, Sikaroodi M, et al. Liver transplant modulates gut microbial dysbiosis and cognitive function in cirrhosis. Liver Transpl. 2017;23(7):907-914.

58. Ahluwalia V, Wade JB, Heuman DM, et al. Enhancement of functional connectivity, working memory and inhibitory control on multi-modal brain MR imaging with rifaximin in cirrhosis: implications for the gut-liver-brain axis. Metab Brain Dis. 2014;29(4):1017-1025.

59. Chen C-H, Lin C-L, Kao C-H. Irritable bowel syndrome is associated with an increased risk of dementia: a nationwide population-based study. PLoS One. 2016;11(1):e0144589.

60. Xu R, Wang Q. Towards understanding brain-gut-microbiome connections in Alzheimer's disease. BMC Syst Biol. 2016;10(S3):63.

61. Andreadou E, Pantazaki AA, Daniilidou M, Tsolaki M. Rhamnolipids, microbial virulence factors, in Alzheimer's disease. J Alzheimers Dis. 2017;59(1):209-222.

62. Zhao Y, Jaber V, Lukiw WJ. Secretory products of the human GI tract microbiome and their potential impact on Alzheimer's disease (AD): detection of lipopolysaccharide (LPS) in AD hippocampus. Front Cell Infect Microbiol. 2017;7:318.

63. Paley EL, Merkulova-Rainon T, Faynboym A, Shestopalov VI, Aksenoff I. Geographical distribution and diversity of gut microbial NADH:ubiquinone oxidoreductase sequence associated with Alzheimer's disease. J Alzheimers Dis. 2018;61(4):1531-1540.

64. Araos R, Andreatos N, Ugalde J, et al. Fecal microbiome among nursing home residents with advanced dementia and Clostridium difficile. Dig Dis Sci. Epub 2018 Mar 28.

65. Cattaneo A, Cattane N, Galluzzi S, et al. Association of brain amyloidosis with pro-inflammatory gut bacterial taxa and peripheral inflammation markers in cognitively impaired elderly. Neurobiol Aging. 2017;49:60-68.

66. Vogt NM, Kerby RL, Dill-Mcfarland KA, et al. Gut microbiome alterations in Alzheimer's disease. Sci Rep. 2017;7(1):13537.

67. Zhuang ZQ, Shen LL, Li WW, et al. Gut microbiota is altered in patients with Alzheimer's disease. J Alzheimers Dis. 2018;63(4): 1337-1346.

68. Qjan Y, Yang Y, Xu S, et al. Alteration of the fecal microbiota in Chinese patients with Parkinson's disease. Brain Behav Immun. Epub 2018 Mar 2.

69. Davari S, Talaei SA, Alaei H, Salami M. Probiotics treatment improves diabetes-induced impairment of synaptic activity and cognitive function: behavioral and electrophysiological proofs for microbiome-gut-brain axis. Neuroscience. 2013;240:287-296.

70. Distrutti E, O'Reilly J-A, Mcdonald C, et al. Modulation of intestinal microbiota by the probiotic VSL\#3 resets brain gene expression and ameliorates the age-related deficit in LTP. PLoS One. 2014;9(9): e106503.

71. Liu J, Sun J, Wang F, et al. Neuroprotective effects of Clostridium butyricum against vascular dementia in mice via metabolic butyrate. Biomed Res Int. 2015;2015:412946.

72. Liang S, Wang $\mathrm{T}, \mathrm{Hu} \mathrm{X}$, et al. Administration of Lactobacillus helveticus NS8 improves behavioral, cognitive, and biochemical aberrations caused by chronic restraint stress. Neuroscience. 2015;310:561-577.

73. Sun J, Wang F, Ling Z, et al. Clostridium butyricum attenuates cerebral ischemia/reperfusion injury in diabetic mice via modulation of gut microbiota. Brain Res. 2016;1642:180-188.
74. Bonfili L, Cecarini V, Berardi S, et al. Microbiota modulation counteracts Alzheimer's disease progression influencing neuronal proteolysis and gut hormones plasma levels. Sci Rep. 2017;7(1):2426.

75. Nimgampalle M, Kuna Y. Anti-Alzheimer properties of probiotic, Lactobacillus plantarum MTCC 1325 in Alzheimer's disease induced albino rats. J Clin Diagn Res. 2017;11(8):KC01-KC05.

76. Kobayashi Y, Sugahara H, Shimada K, et al. Therapeutic potential of Bifidobacterium breve strain A1 for preventing cognitive impairment in Alzheimer's disease. Sci Rep. 2017;7(1):13510.

77. Musa NH, Mani V, Lim SM, Vidyadaran S, Abdul Majeed AB, Ramasamy K. Lactobacilli-fermented cow's milk attenuated lipopolysaccharide-induced neuroinflammation and memory impairment in vitro and in vivo. J Dairy Res. 2017;84(04):488-495.

78. Chunchai T, Thunapong W, Yasom S, et al. Decreased microglial activation through gut-brain axis by prebiotics, probiotics, or synbiotics effectively restored cognitive function in obese-insulin resistant rats. J Neuroinflammation. 2018;15(1):11.

79. Athari Nik Azm S, Djazayeri A, Safa M, et al. Lactobacillus and bifidobacterium ameliorate memory and learning deficits and oxidative stress in A $\beta$ (1-42) injected rats. Appl Physiol Nutr Metab. Epub 2018 Feb 20.

80. Wang D, Ho L, Faith J, et al. Role of intestinal microbiota in the generation of polyphenol-derived phenolic acid mediated attenuation of Alzheimer's disease $\beta$-amyloid oligomerization. Mol Nutr Food Res. 2015;59(6):1025-1040.

81. Yuan T, Ma H, Liu W, et al. Pomegranate's neuroprotective effects against Alzheimer's disease are mediated by urolithins, its ellagitanningut microbial derived metabolites. ACS Chem Neurosci. 2016;7(1): 26-33.

82. Wang S, Huang X-F, Zhang P, et al. Dietary teasaponin ameliorates alteration of gut microbiota and cognitive decline in diet-induced obese mice. Sci Rep. 2017;7(1):12203.

83. Chen D, Yang X, Yang J, et al. Prebiotic effect of fructooligosaccharides from Morinda officinalis on Alzheimer's disease in rodent models by targeting the microbiota-gut-brain axis. Front Aging Neurosci. 2017; 9:403.

84. Gao L, Li J, Zhou Y, Huang X, Qin X, Du G. Effects of baicalein on cortical proinflammatory cytokines and the intestinal microbiome in senescence accelerated mouse prone 8. ACS Chem Neurosci. 2018;9(7):1714-1724.

85. Benton D, Williams $\mathrm{C}$, Brown A. Impact of consuming a milk drink containing a probiotic on mood and cognition. Eur J Clin Nutr. 2007;61(3): 355-361.

86. Allen AP, Hutch W, Borre YE, et al. Bifidobacterium longum 1714 as a translational psychobiotic: modulation of stress, electrophysiology and neurocognition in healthy volunteers. Transl Psychiatry. 2016; 6(11):e939.

87. Kelly JR, Allen AP, Temko A, et al. Lost in translation? The potential psychobiotic Lactobacillus rhamnosus (JB-1) fails to modulate stress or cognitive performance in healthy male subjects. Brain Behav Immun. 2017;61:50-59.

88. Carlsson M, Gustafson Y, Haglin L, Eriksson S. The feasibility of serving liquid yoghurt supplemented with probiotic bacteria, Lactobacillus rhamnosus LB 21, and Lactococcus lactis L1A - a pilot study among old people with dementia in a residential care facility. J Nutr Health Aging. 2009;13(9):813-819.

89. Mancuso C, Santangelo R. Alzheimer's disease and gut microbiota modifications: the long way between preclinical studies and clinical evidence. Pharmacol Res. 2018;29:329-336.

90. Morris JK, Honea RA, Vidoni ED, Swerdlow RH, Burns JM. Is Alzheimer's disease a systemic disease? Biochim Biophys Acta. 1842; 2014(9):1340-1349.

91. Tremlett H, Bauer KC, Appel-Cresswell S, Finlay BB, Waubant E. The gut microbiome in human neurological disease: a review. Ann Neurol. 2017;81(3):369-382.

92. Dinan TG, Cryan JF. Gut insticts: microbiota as a key regulator of brain development, ageing and neurodegeneration. J Physiol. 2017; 595(2):489-503. 
93. Franceschi C, Garagnani P, Morsiani C, et al. The continuum of aging and age-related diseases: common mechanisms but different rates. Front Med. 2018;5:61.

94. Itzhaki RF, Lathe R, Balin BJ, et al. Microbes and Alzheimer's disease. J Alzheimers Dis. 2016;51(4):979-984.

95. Friedland RP, Chapman MR. The role of microbial amyloid in neurodegeneration. PLoS Pathog. 2017;13(12):e1006654.

96. Köhler C, Maes M, Slyepchenko A, et al. The gut-brain axis, including the microbiome, leaky gut and bacterial translocation: mechanisms and pathophysiological role in Alzheimer's disease. Curr Pharm Des. 2016;22(40):6152-6166.

97. Pistollato F, Sumalla Cano S, Elio I, Masias Vergara M, Giampieri F, Battino M. Role of gut microbiota and nutrients in amyloid formation and pathogenesis of Alzheimer disease. Nutr Rev. 2016;74(10):624-634

98. Friedland RP. Mechanisms of molecular mimicry involving the microbiota in neurodegeneration. J Alzheimers Dis. 2015;45(2):349-362.

99. Ticinesi A, Milani C, Gerritsen J, et al. Gut microbiota composition and Clostridium difficile infection in hospitalized elderly individuals: a metagenomic study. Sci Rep. 2016;6:25945.

100. Mancabelli L, Milani C, Lugli GA, et al. Unveiling the gut microbiota composition and functionality associated with constipation through metagenomic analyses. Sci Rep. 2017;7(1):9879.

101. Li CQ, Zheng Q, Wang Q, Zeng QP. Biotic/abiotic stress-driven Alzheimer's disease. Front Cell Neurosci. 2016;10:269.

102. Bhattacharjee S, Lukiw WJ. Alzheimer's disease and the microbiome Front Cell Neurosci. 2013;7:153.

103. Westfall S, Lomis N, Kahouli I, et al. Microbiome, probiotics and neurodegenerative diseases: deciphering the gut brain axis. Cell $\mathrm{Mol}$ Life Sci. 2017;74(20):3769-3787.

104. Alkasir R, Li J, Li X, Jin M, Zhu B. Human gut microbiota: the links with dementia development. Protein Cell. 2017;8(2):90-102.

105. Stilling RM, van de Wouw M, Clarke G, Stanton C, Dinan TG, Cryan JF. The neuropharmacology of butyrate: the bread and butter of the microbiota-gut-brain axis? Neurochem Int. 2016;99:110-132.

106. Shoemark DK, Allen SJ. The microbiome and disease: reviewing the links between the oral microbiome, aging, and Alzheimer's disease. J Alzheimers Dis. 2015;43(3):725-738.

107. Harding A, Gonder U, Robinson SJ, Crean S, Singhrao SK. Exploring the association between Alzheimer's disease, oral health, microbial endocrinology and nutrition. Front Aging Neurosci. 2017;9:398.

108. Leung K, Thuret S. Gut microbiota: a modulator of brain plasticity and cognitive function in ageing. Healthcare (Basel). 2015;3(4):898-916.

109. Prenderville JA, Kennedy PJ, Dinan TG, Cryan JF. Adding fuel to the fire: the impact of stress on the ageing brain. Trends Neurosci. 2015; 38(1):13-25.

110. Daulatzai MA. Chronic functional bowel syndrome enhances gutbrain axis dysfunction, neuroinflammation, cognitive impairment, and vulnerability to dementia. Neurochem Res. 2014;39(4):624-644.

111. Solfrizzi V, Custodero C, Lozupone M, et al. Relationships of dietary patterns, foods, and micro- and macronutrients with Alzheimer's disease and late-life cognitive disorders: a systematic review. J Alzheimers Dis. 2017;59(3):815-849.

112. Caracciolo B, Xu W, Collins S, Fratiglioni L. Cognitive decline, dietary factors and gut-brain interactions. Mech Ageing Dev. 2014;136-137: 59-69.
113. Zhang N, Ju Z, Zuo T. Time for food: the impact of diet on gut microbiota and human health. Nutrition. 2018;51-52:80-85.

114. Milani C, Ferrario C, Turroni F, et al. The human gut microbiota and its interactive connections to diet. J Hum Nutr Diet. 2016;29(5): 539-546.

115. Arumugam M, Raes J, Pelletier E, et al. Enterotypes of the human gut microbiome. Nature. 2011;473(7346):174-180.

116. Noble EE, Hsu TM, Kanoski SE. Gut to brain dysbiosis: mechanisms linking western diet consumption, the microbiome, and cognitive impairment. Front Behav Neurosci. 2017;11:9.

117. Russo R, Cristiano C, Avagliano C, et al. Gut-brain axis: role of lipids in the regulation of inflammation, pain and CNS diseases. Curr Med Chem. 2017;24:1-22.

118. Pasinetti GM, Singh R, Westfall S, Herman F, Faith J, Ho L. The role of the gut microbiota in the metabolism of polyphenols as characterized by gnotobiotic mice. J Alzheimers Dis. 2018;63(2):409-421.

119. Ludwig IA, Mena P, Calani L, et al. New insights into the bioavailability of red raspberry anthocyanins and ellagitannins. Free Radic Biol Med. 2015;89:758-769.

120. Shen L, Ji HF. Bidirectional interactions between dietary curcumin and gut microbiota. Crit Rev Food Sci Nutr. 2018:1-28.

121. Yan FS, Sun JL, Xie WH, Shen L, Ji HF. Neuroprotective effects and mechanisms of curcumin- $\mathrm{Cu}$ (II) and $-\mathrm{Zn}$ (II) complexes systems and their pharmacological implications. Nutrients. 2018 10(1):28.

122. Rane JS, Bhaumik P, Panda D. Curcumin inhibits tau aggregation and disintegrates preformed tau filaments in vitro. $J$ Alzheimers Dis. 2017;60(3):999-1014.

123. Tabira T, Kawamura N. A study of a supplement containing huperzine a and curcumin in dementia patients and individuals with mild cognitive impairment. J Alzheimers Dis. 2018;63(1):75-78.

124. Singh V, Roth S, Llovera G, et al. Microbiota dysbiosis controls the neuroinflammatory response after stroke. J Neurosci. 2016;36(28): 7428-7440.

125. Solas M, Milagro FI, Ramírez MJ, Martínez JA. Inflammation and gut-brain axis link obesity to cognitive dysfunction: plausible pharmacological interventions. Curr Opin Pharmacol. 2017;37:87-92.

126. Xu Y, Zhou H, Zhu Q. The impact of microbiota-gut-brain axis on diabetic cognition impairment. Front Aging Neurosci. 2017;9:106.

127. Li S, Shao Y, Li K, et al. Vascular cognitive impairment and the gut microbiota. J Alzheimers Dis. 2018;63(4):1209-1222.

128. Zheng X, Zhang X, Kang A, Ran C, Wang G, Hao H. Thinking outside the brain for cognitive improvement: is peripheral immunomodulation on the way? Neuropharmacology. 2015;96:94-104.

129. Wang H, Lee IS, Braun C, Enck P. Effect of probiotics on central nervous system functions in animals and humans: a systematic review. J Neurogastroenterol Motil. 2016;22(4):589-605.

130. Sarkar A, Lehto SM, Harty S, Dinan TG, Cryan JF, Burnet PWJ Psychobiotics and the Manipulation of bacteria-gut-brain signals. Trends Neurosci. 2016;39(11):763-781.

131. smart.servier.com [homepage on the Internet]. 3000 free medical images to illustrate your publications and PowerPoint presentations; 2018. Accessed on May 20th 2018.

132. pixabay.com [homepage on the Internet]; 2018. Accessed on May 20th 2018
Clinical Interventions in Aging

\section{Publish your work in this journal}

Clinical Interventions in Aging is an international, peer-reviewed journal focusing on evidence-based reports on the value or lack thereof of treatments intended to prevent or delay the onset of maladaptive correlates of aging in human beings. This journal is indexed on PubMed Central, MedLine,

\section{Dovepress}

CAS, Scopus and the Elsevier Bibliographic databases. The manuscript management system is completely online and includes a very quick and fair peer-review system, which is all easy to use. Visit http://www.dovepress. com/testimonials.php to read real quotes from published authors. 